\title{
NGNP Risk Management through Assessing Technology Readiness Status
}

The INL is a

U.S. Department of Energy National Laboratory

operated by

Battelle Energy Alliance

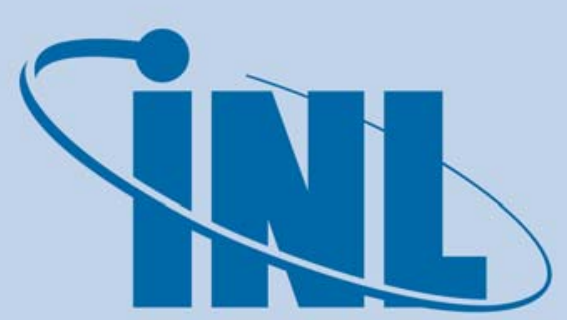

Idaho National Laboratory

August 2010

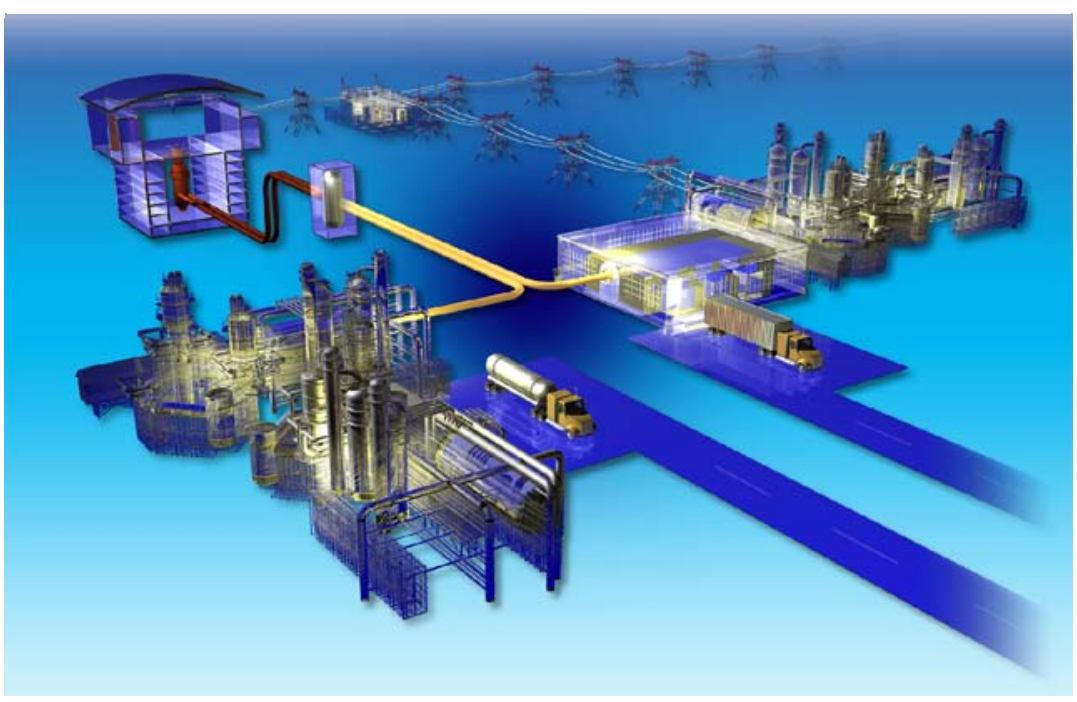




\section{DISCLAIMER}

This information was prepared as an account of work sponsored by an agency of the U.S. Government. Neither the U.S. Government nor any agency thereof, nor any of their employees, makes any warranty, expressed or implied, or assumes any legal liability or responsibility for the accuracy, completeness, or usefulness, of any information, apparatus, product, or process disclosed, or represents that its use would not infringe privately owned rights. References herein to any specific commercial product, process, or service by trade name, trade mark, manufacturer, or otherwise, does not necessarily constitute or imply its endorsement, recommendation, or favoring by the U.S. Government or any agency thereof. The views and opinions of authors expressed herein do not necessarily state or reflect those of the U.S. Government or any agency thereof. 


\title{
NGNP Risk Management through Assessing Technology Readiness Status
}

August 2010

\author{
Idaho National Laboratory \\ Next Generation Nuclear Plant Project \\ Idaho Falls, Idaho 83415
}

http://www.inl.gov

Prepared for the

U.S. Department of Energy

Office of Nuclear Energy

Under DOE Idaho Operations Office

Contract DE-AC07-05ID14517 
Next Generation Nuclear Plant (NGNP) Project

\section{NGNP Risk Management through Assessing Technology Readiness Status}

August 2010

Authored by:
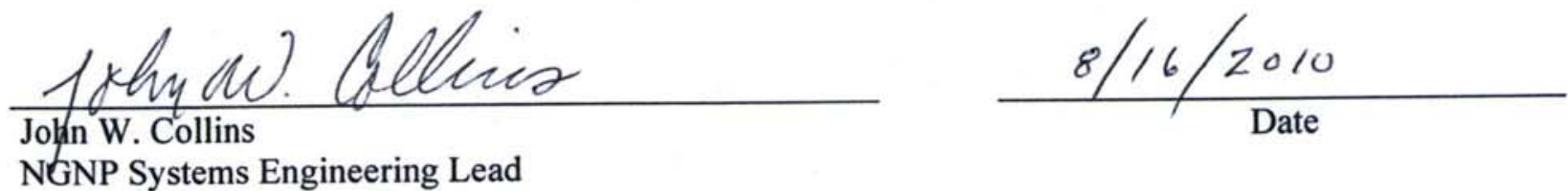

NGNP Systems Engineering Lead

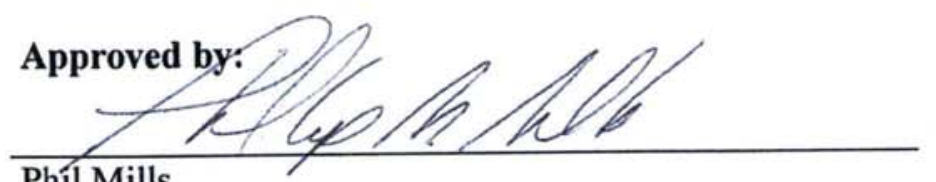

Phíl Mills

NGNP Acting Engineering Director

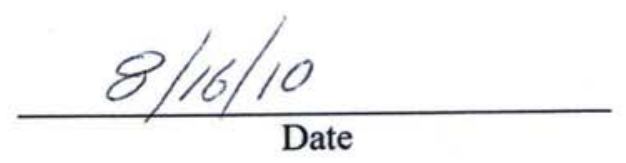




\section{CONTENTS}

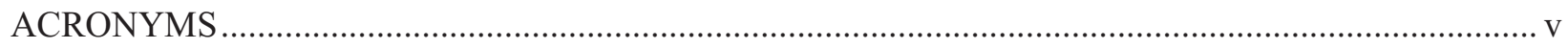

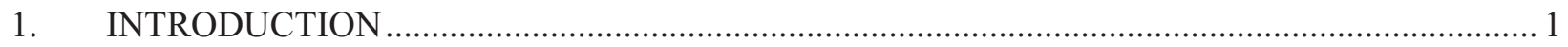

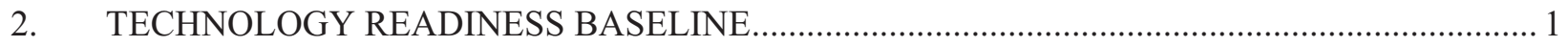

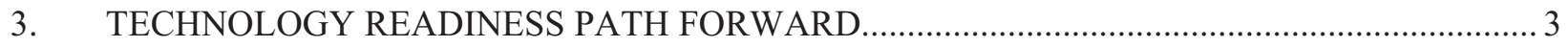

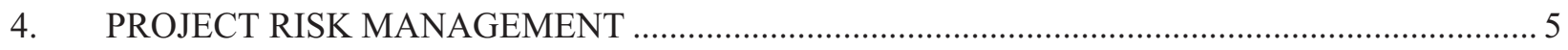

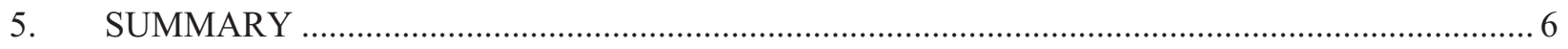

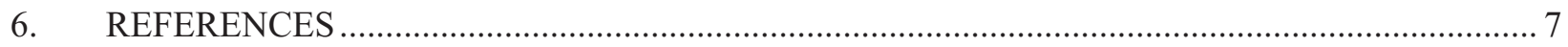

\section{FIGURES}

Figure 1. Technical readiness advances in parallel with increasingly detailed design .............................. 1

Figure 2. An example of a Technology Development Roadmap ............................................................. 4

TABLES

Table 1. NGNP Risk Management Approach..................................................................................... 1

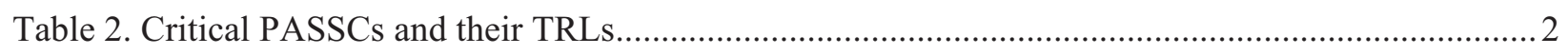

Table 3. Risk types as defined by the INCOSE Systems Engineering Handbook ${ }^{24}$................................. 3

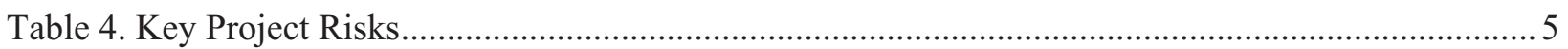




\section{ACRONYMS}

ASME American Society of Mechanical Engineers

ASTM American Society for Testing and Materials

DDN Design Data Need

DOE U.S. Department of Energy

HTGR Temperature Gas-cooled Reactor

INL Idaho National Laboratory

ITRG Independent Technical Review Group

NGNP Next Generation Nuclear Plant

NRC Nuclear Regulatory Commission

PASSC plant, area, structure, system, or component

PIRT Phenomena Identification and Ranking Table

ROT Reactor Outlet Temperature

R\&D research and development

RMS Risk Management System

SSC structure, system, or component

TRL Technology Readiness Level 


\section{NGNP Risk Management through Assessing Technology Readiness Status}

\section{INTRODUCTION}

Throughout the Next Generation Nuclear Plant (NGNP) project life cycle, technical risks will be identified, analyzed, and mitigated and decisions will be made regarding the design and selection of plant and sub-system configurations, components and their fabrication materials, and operating conditions. Risk resolution and decision making are key elements that help achieve project completion within budget and schedule constraints and desired plant availability. To achieve this objective, a formal decisionmaking and risk management process was developed for NGNP, based on proven systems engineering principles that have guided aerospace and military applications.

NGNP project risk management ${ }^{2}$ follows Idaho National Laboratory (INL) ${ }^{3}$ and U.S. Department of Energy (DOE) $)^{1,4,5}$ guidelines and includes the identification, impact assessment, and prioritization of technical and programmatic risks followed by a coordinated application of resources to mitigate or eliminate risks that may impact the successful outcome of the project. This requires that: (1) technical and programmatic risks be identified, quantified, and mitigated, as appropriate; and (2) risk mitigation strategies be developed, documented, and implemented. Risk methodology developed and applied for the NGNP project (see Table 1) includes systems for reporting and tracking risks, risk status, and risk resolution. Risk management will enhance the probability of NGNP project success by improving project performance and decreasing the likelihood of unanticipated cost overruns, schedule delays, and compromises in quality and safety, which are often caused by reliance on immature technologies. ${ }^{6}$

Table 1. NGNP Risk Management Approach

- Risk management planning

- Risk identification

- Risk quantification and prioritization

- Risk response

- Risk impact determination

- Risk tracking and reporting

\section{TECHNOLOGY READINESS BASELINE}

A Technology Readiness Assessment was conducted to estimate the maturity of systems and components and further understand the risk associated with their design, manufacture, and operational performance. Through this assessment, a technical maturity baseline was established using scales called Technology Readiness Levels (TRLs; see Figure 1). TRL ratings for NGNP: (1) are on a scale of 1-10; (2) use the current development state of proposed technologies as their starting points; and (3) provide a consistent measure of readiness and confidence in the structure's, system's, or component's (SSC) ability to reliably perform its function.

The Technology Readiness Assessment established the technology maturity baseline and included a review of the potential architecture

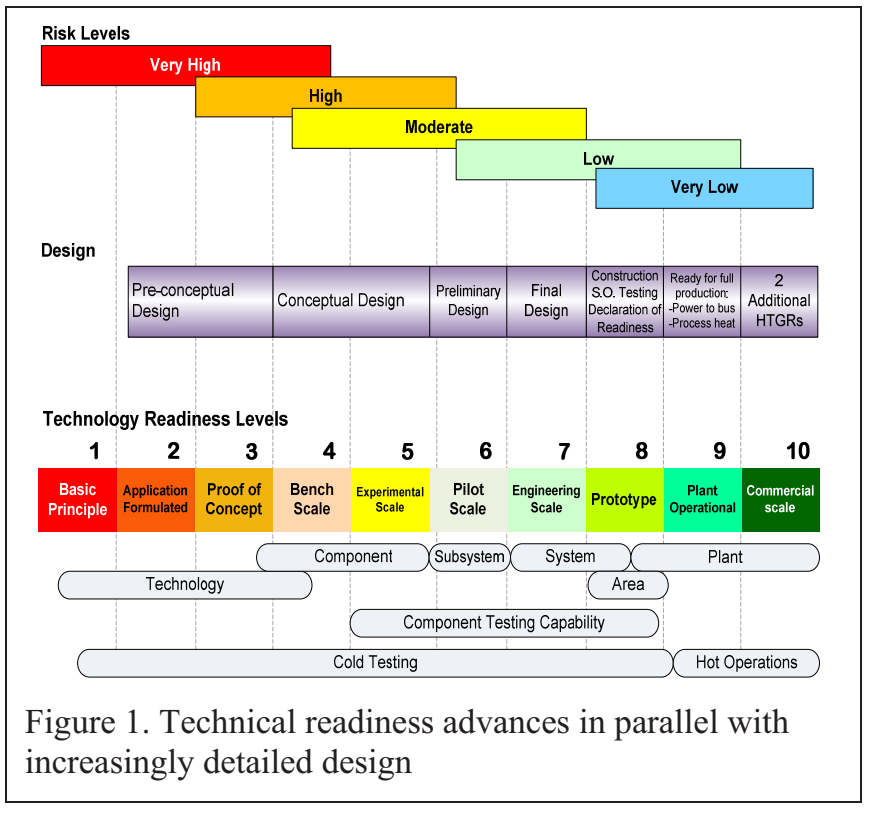
and concept of operations needed to satisfy NGNP stakeholder requirements. 
The assessment determined that there were 16 critical SSCs for the five areas of the NGNP: nuclear heat supply; heat transport, hydrogen production, power conversion, and balance of plant. SSCs are required to perform the desired functions and meet the needs specified by the project. Critical SSCs, at a minimum, were defined as those components that are not commercially available or do not have proven industry experience in an environment relevant to the NGNP. Critical SSCs for each plant area were identified for reactor outlet temperatures (ROT) of $950^{\circ} \mathrm{C} \mathrm{NGNP}^{7}$ and for $750-800^{\circ} \mathrm{C}$ NGNP. ${ }^{8}$ Critical SSCs may change as the NGNP develops. The critical SSCs and associated TRLs, as of August 2009, are shown in Table 2 for ROT of $950^{\circ} \mathrm{C}$ and $750-800^{\circ} \mathrm{C}$.

Whether reflective of the $950^{\circ} \mathrm{C}$ or $750-$ $800^{\circ} \mathrm{C}$ ROT, the TRLs serve as an excellent measure to integrate research and development (R\&D) activities with the necessary design and licensing activities anticipated for the NGNP. Just as immature technologies inserted into a plant can cause problems, designs need to advance to the point of informing R\&D of needed tasks to better the design. As depicted in Figure 1, very high risks and low technology readiness are acceptable in the early stages of design. As the design advances, the risk should be reduced and the technology readiness increased. As the technology achieves the performance criteria required for advancing technology readiness, the uncertainty associated with the successful implementation of that technology is reduced. In this fashion, technical and programmatic risk (see Table 3 ) is reduced as technology readiness levels increase. The NGNP Risk Register currently includes technical risk, while programmatic risks are being evaluated for inclusion in the register.
Table 2. Critical PASSCs and their TRLs

\begin{tabular}{|c|c|c|c|c|}
\hline \multicolumn{5}{|c|}{ NGNP Cons olidated } \\
\hline Section & TDRM $-750^{\circ} \mathrm{C}$ & $\begin{array}{l}\text { TRL - } \\
750^{\circ} \mathrm{C}\end{array}$ & TDRM $-950^{\circ} \mathrm{C}$ & $\begin{array}{l}\text { TRL- } \\
950^{\circ} \mathrm{C}\end{array}$ \\
\hline \multicolumn{5}{|c|}{ Nuclear Heat Supply } \\
\hline 2.1 & Reactor Pressure Vessel & 4 & Reactor Pressure Vessel & 4 \\
\hline 2.2 & Reactor Vessel Internals & 4 & Reactor Vessel Internals & 4 \\
\hline 2.3 & $\begin{array}{l}\text { Reactor Core \& Core } \\
\text { Structure }\end{array}$ & 4 & $\begin{array}{l}\text { Reactor Core \& Core } \\
\text { Structure }\end{array}$ & 5 \\
\hline 2.4 & Fuel Elements & 4 & Fuel Elements & 4 \\
\hline 2.5 & $\begin{array}{l}\text { Reserve Shutdown } \\
\text { System }\end{array}$ & 5 & $\begin{array}{l}\text { Reserve Shutdown } \\
\text { System }\end{array}$ & 5 \\
\hline 2.6 & Reactivity Control System & 4 & Reactivity Control System & 4 \\
\hline 2.7 & Core Conditioning System & 4 & Core Conditioning System & 4 \\
\hline 2.8 & $\begin{array}{l}\text { Reactor Cavity Cooling } \\
\text { System }\end{array}$ & 4 & $\begin{array}{l}\text { Reactor Cavity Cooling } \\
\text { System }\end{array}$ & 4 \\
\hline \multicolumn{5}{|c|}{ Heat Transfer System } \\
\hline 3.1 & Circulators & 5 & Circulators & 4 \\
\hline 3.2 & $\begin{array}{l}\text { Intermediate Heat } \\
\text { Exchangers }\end{array}$ & 3 & $\begin{array}{l}\text { Intermediate Heat } \\
\text { Exchangers }\end{array}$ & 3 \\
\hline 3.3 & Cross Vessel Piping & 4 & Cross Vessel Piping & 4 \\
\hline 3.4.1 & $\begin{array}{l}\text { High Temperature Valves } \\
\text { Flapper }\end{array}$ & 6 & \multirow{2}{*}{$\begin{array}{c}\text { High Temperature Valves } \\
\text { (Flapper and Isolation, } \\
\text { Relief) }\end{array}$} & 5 \\
\hline 3.4.2 & $\begin{array}{l}\text { High Temperature Valves } \\
\text { Isolation, Relief }\end{array}$ & 4 & & 3 \\
\hline 3.5 & $\mathrm{n} / \mathrm{a}$ & & Mixing Chamber & 6 \\
\hline \multicolumn{5}{|c|}{ Hydrogen Production System } \\
\hline 4.1 & $\mathrm{n} / \mathrm{a}$ & & $\begin{array}{l}\text { Hydrogen Production } \\
\text { System }\end{array}$ & \\
\hline \multicolumn{5}{|c|}{ Power Conversion System } \\
\hline 5.1 & Steam Generator & 4 & Steam Generator & 4 \\
\hline 5.2 & $\mathrm{n} / \mathrm{a}$ & & $\begin{array}{l}\text { PCS Equipment for Direct } \\
\text { Combined Cycle * }\end{array}$ & 4 \\
\hline \multicolumn{5}{|c|}{ Balance of Plant } \\
\hline 6.1 .1 & $\begin{array}{l}\text { Fuel Handling System- } \\
\text { Prismatic }\end{array}$ & 4 & \multirow{2}{*}{$\begin{array}{l}\text { Fuel Handling System- } \\
\text { Prismatic Only }\end{array}$} & \multirow{2}{*}{4} \\
\hline 6.1 .2 & $\begin{array}{l}\text { Fuel Handling System- } \\
\text { Pebble Bed }\end{array}$ & 5 & & \\
\hline 6.2 & $\begin{array}{l}\text { Instrumentation and } \\
\text { Control }\end{array}$ & 3 & $\begin{array}{l}\text { Instrumentation and } \\
\text { Control }\end{array}$ & 3 \\
\hline & \multicolumn{4}{|c|}{ Total Number of Critical PASSCs } \\
\hline & \multicolumn{4}{|c|}{ NGNP Consolidated } \\
\hline & TDRM - $750^{\circ} \mathrm{C}$ & 15 & TDRM $-950^{\circ} \mathrm{C}$ & 18 \\
\hline & Legend & & & \\
\hline & TRL decreased at $750^{\circ} \mathrm{C}$ & & & \\
\hline & TRL increased at $750^{\circ} \mathrm{C}$ & & & \\
\hline
\end{tabular}




\section{TECHNOLOGY READINESS PATH FORWARD}

With the baseline critical SSCs and their associated TRLs defined, experts from DOE national laboratories and gas-cooled reactor vendors established technology development "roadmaps"7,8 and developed the documents $^{9}$ that outlined the licensing ${ }^{10,11}$, engineering design ${ }^{12,13}$, and $\mathrm{R} \& \mathrm{D}^{14,15,16,17,18}$ activities required to guide the technology maturation process. Roadmaps (see Figure 2) set the project course for technology selection and qualification, and for the integration of developing components into mature and operable systems.

The roadmaps include detailed descriptions of the required technical activities, with associated schedules and cost estimates for project completion, as well as the integration of needed research, development, and qualification activities. The roadmap identifies: (1) key selection discriminators; (2) key technology decision points and the scientific and technical information necessary to make informed technology selections; (3) current TRL assessments; (4) development tasks needed to mature technologies; and (5) test plans to advance TRL assessments for components and systems. Roadmaps facilitate the ability of the project to successfully meet scheduling and budgeting demands. To support project management, technology roadmaps: (1) align short-term and long-term goals and identify the technology development activities needed to meet those goals; (2) focus resources on critical technologies; (3) provide early identification and management of technical and programmatic risks; and (4) ensure technology readiness is demonstrated through testing, modeling, pilot scale testing, and prototyping.

Table 3. Risk types as defined by the INCOSE Systems Engineering Handbook $^{24}$

Technical risk is the possibility that a technical requirement of the system may not be achieved in the system life cycle. Technical risk exists if the system may fail to achieve performance requirements; to meet operability, producability, testability, or integration requirements; or to meet environmental protection requirements. A potential failure to meet any requirement that can be expressed in technical terms is a source of technical risk.

Programmatic risk is produced by events that are beyond the control of the project manager. These events often are produced by decisions made by personnel at higher levels of authority, such as reductions in project priority, delays in receiving authorization to proceed with a project, reduced or delayed funding, changes in organization or national objectives, etc. 


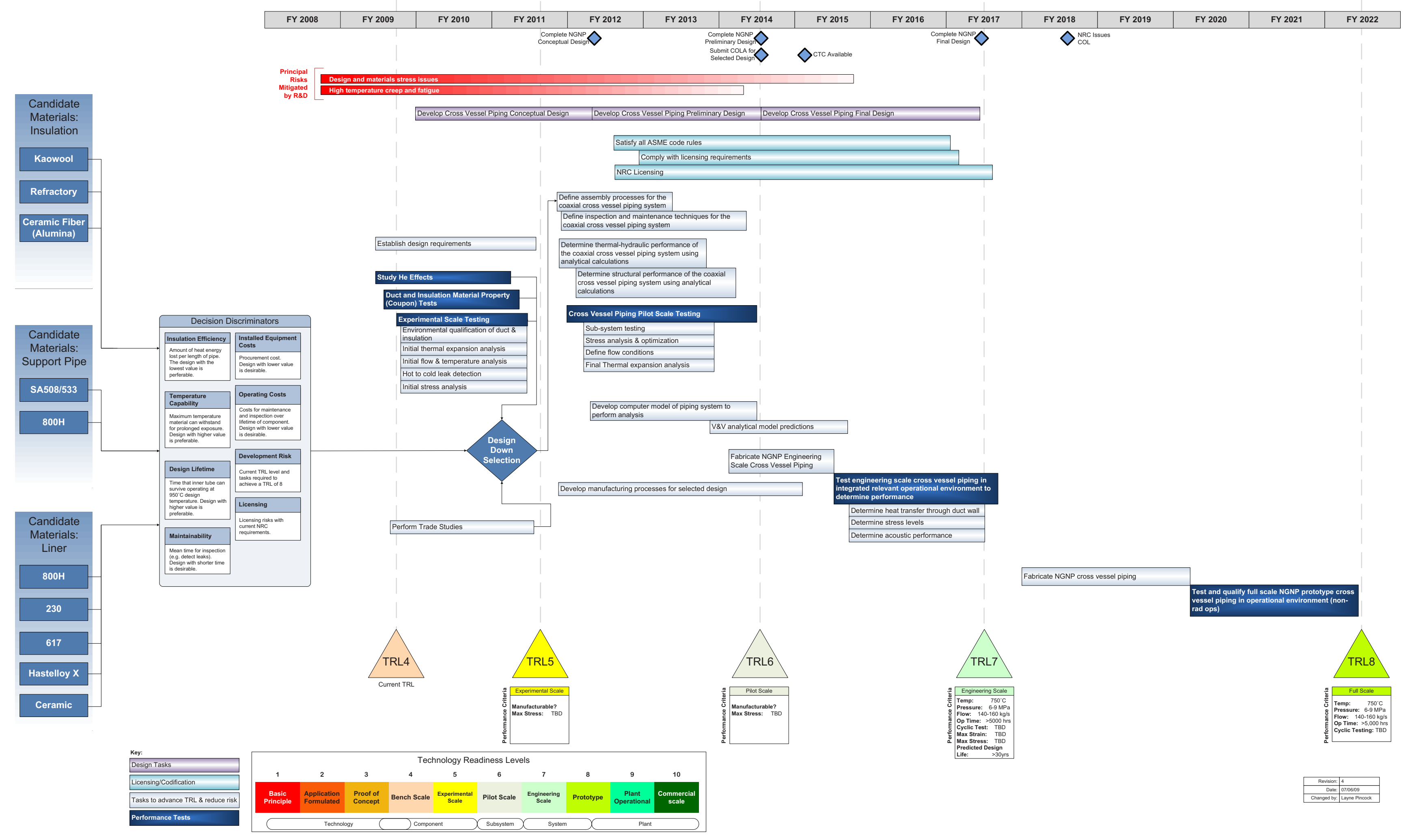

Figure 2. An example of a Technology Development Roadmap 


\section{PROJECT RISK MANAGEMENT}

The NGNP Risk Management System (RMS) was developed as a risk management and tracking capability. The RMS is used to establish the Project Risk Register, which includes the list of project risks, the risk reduction plan, and the current risk reduction status, each of which is organized by reference configurations for critical plant, area, systems, subsystem or structures, and/or components (PASSCs). The RMS allows rollup/drilldown analysis that summarizes quantitative risk scores using various levels of data and information details. The risk scores can be displayed for either the baseline, current status, or the final projected risk. Risks can be rolled up by average or worst case for a selected design configuration. The tool's hierarchy tree also allows the visualization and analyses of the complex relationships between various NGNP project entities, for example, PASSCs, risks, risk mitigation tasks, design data needs (DDNs), and phenomena identification and ranking tables (PIRTs). DDNs are a means of identifying the technologies which require additional research and development for the successful deployment of the HTGR. Likewise, PIRTs are a means of documenting the NCR identified phenomena and data required to support safety analysis and licensing of HTGRs. Linking the DDNs and PIRTs to the project risk allows the project to assure that these needs are addressed. One can analyze risks at the plant or area level and align the risk with any likely Work Breakdown Structure for scope and financial planning that addresses risk. Additional RMS functionality includes the ability to analyze and track relational mapping between project risks and PIRTs, risk reduction tasks, and DDNs, thus facilitating gap identification in planning R\&D activities. The status of the risk handling strategy is primarily based on the percent completion of risk reduction tasks and may be displayed graphically by plotting the actual/current risk reduction versus the planned risk reduction over time. For tasks that provide a reduction in risk for more than one risk item, the tool provides the ability to summarize its contribution across the entire NGNP risk plan. This capability makes it possible to rank order tasks by the magnitude of risk reduction provided for the entire project and provides valuable input into NGNP project planning and prioritization.

Additionally, these tasks are directly related to the line items from an integrated schedule and allow risk tracking as progress against schedule is accomplished.

The results of the pre-conceptual design have formed the foundation upon which the design of the NGNP will evolve through a process of progressive selection of design conditions and features. To make these selections, project personnel must understand the risks associated with design, licensing, and commercialization; understand the factors that affect risk resolution; and balance the timing and risk of technology development with the deployment schedule. Project personnel must also understand the needs, applications, and expectations of the private sector. In the early phase of conceptual design, technology risk factors were addressed by technology selection and design development studies followed by the 
actual conceptual design. Deployment and application risks are being explored with the industry and through meetings and discussions with potential end-users.

High-level technical requirements were established for the project ${ }^{22}$ and an independent technical review group (ITRG) has assessed the risks associated with development and demonstration of the technology. ${ }^{23}$ The ITRG assessment provided a comprehensive summary of technical issues that must be resolved for successful implementation of the High Temperature Gas-cooled Reactor (HTGR) technology. The pre-conceptual design work has confirmed, in general, the conclusions on the technical risks described in the ITRG report.

Reactor power level, reactor core gas inlet and outlet temperatures, and primary system pressure are the NGNP operating conditions that have the most impact on the significance of identified risks (see Table 4). Temperature and pressure affect the required capabilities of materials in the nuclear heat supply system and impact the demonstration of commercialization. The metallic material risks derive from uncertainties in qualification, availability, and the ability to fabricate large components out of materials that can reliably operate at the high gas temperatures. Reactor fuel risks emerge due to concerns regarding fuel development, qualification, and acquisition. Risks due to graphite derive from issues pertaining to qualification, availability, and fabrication processes and fabrication facilities.

While the issues pertaining to fuel, graphite, and metallic materials are being addressed by NGNP $\mathrm{R} \& \mathrm{D}$, these material risks have added uncertainty as to whether the NGNP can be successfully completed on time. An example of a risk reducing strategy is found in the potential use of a phased approach to achieving the objective design operating conditions. In this approach, the plant would be operated at a lower than design temperature during early operations to provide more design margin for the currently available materials. The phased operation approach would provide additional time to expand the materials databases and further qualify the materials for use in high-temperature environments.

Another example of a risk reduction strategy in the NGNP has to do with the Reactor Pressure Vessel outlet temperature (ROT). By moving to a ROT of $750-800^{\circ} \mathrm{C}$ for a first-of-a-kind NGNP rather than a $950^{\circ} \mathrm{C}$ ROT and the down-selection to the SA508/533 alloy, the overall risk of the RPV is reduced. Using the RMS as a risk tracking and analysis tool, we determine that through the temperature reduction and alloy selection, the normalized risk was reduced from high risk to moderate risk. While the TRL for each scenario remains the same $(\mathrm{TRL}=4)$, the path forward as depicted in the Technology Development Roadmap is significantly less onerous.

\section{SUMMARY}

The risk management and decision making process have identified design criteria, established TRLs for critical SSCs, and developed technology roadmaps ${ }^{19,20,21}$ that identify the technology development actions needed to advance the TRLs and ensure that critical plant SSCs will be sufficiently mature for reliable plant operation. To meet this need, NGNP has developed several tracking and analysis tools. The Technology Development Roadmaps serve to assure that the various laboratory, industry, and university participants are focused on the correct technology maturation, qualification, and readiness activities for reliable plant operation. The NGNP Risk Management System tracks the project risk and focuses the project in identifying and reducing risk early in the project cycle, while systematically enhancing technological readiness. This systematic method has also increased confidence in the success of the project (i.e., meeting cost and schedule objectives) at the completion of each phase of design development. 


\section{REFERENCES}

1. DOE O 413.3A, "Program and Project Management for the Acquisition of Capital Assets," U.S. Department of Energy, July 28, 2006. https://www.directives.doe.gov/directives/currentdirectives/413.3-Border-ac1/view

2. INL, Technical Risk Management for the NGNP Project, INL/EXT-07-13148, Idaho National Laboratory, September 2007.

3. LWP-7350, "Project Risk Management," Rev. 1, August 3, 2009.

4. DOE G 413.3-7, “Risk Management Guide,” U.S. Department of Energy, September 16, 2008.

5. DOE M 413.3-1, "Project Management for the Acquisition of Capital Assets, Section I, Chapter 14, "Risk Management," U.S. Department of Energy, March 28, 2003.

6. GAO, Department of Energy: Major Construction Projects Need a Consistent Approach for Assessing Technology Readiness to Help Avoid Cost Increases and Delays, GAO-07-336, U.S. Government Accountability Office, March 2007.

7. INL, Next Generation Nuclear Plant Project Technology Development Roadmaps: The Technical Path Forward, INL/EXT-08-15148, Idaho National Laboratory, January 2009.

8. INL, Next Generation Nuclear Plant Project Technology Development Roadmaps: The Technical Path Forward for 750-800 ${ }^{\circ} \mathrm{C}$ Reactor Outlet Temperature, INL/EXT-09-16598, Idaho National Laboratory, August 2009.

9. PLN-2825, "Next Generation Nuclear Plant Project (NGNP) Preliminary Project Execution Plan," September 2009.

10. DOE, Next Generation Nuclear Plant Licensing Strategy: A Report to Congress, U.S. Department of Energy, August 2008.

11. PLN-3202, “NGNP Licensing Plan,” June 2009.

12. PLN-3206, “NGNP Project Requirements Management Implementation Plan,” June 2009.

13. INL, NGNP Systems Requirements Manual, INL/EXT-07-12999, Rev. 3, Idaho National Laboratory, September 2009.

14. PLN-2494, “VHTR Technology Development Office Program Management Plan,” June 2009.

15. INL, Technical Program Plan for the Next Generation Nuclear Plant/Advanced Gas Reactor Fuel Development and Qualification Program, INL/EXT-05-00465, Rev 2, Idaho National Laboratory, July 2008.

16. PLN-2497, “Graphite Technology Plan,” October 2007.

17. PLN-2674, "Next Generation Nuclear Plant Materials Research and Development Program Plan," October 2007.

18. PLN-2498, "Next Generation Nuclear Plant Methods Research and Development Technical Program Plan," September 2008.

19. AREVA, NGNP Technology Development Road Mapping Report, Prepared by AREVA, TDR3001031-003, AREVA Federal Services, LLC, September 2009.

20. General Atomics, Engineering Services for the Next Generation Nuclear Plant (NGNP) with Hydrogen Production: Technology Development Road Mapping Report for NGNP with $750^{\circ} \mathrm{C}$ 
Reactor Outlet Helium Temperature, Prepared by General Atomics, PC-000586, General Atomics, May 2009.

21. Westinghouse Electric Company, Next Generation Nuclear Plant Report on Technology Readiness Levels \& Design Readiness Levels for NGNP Steam Production at 750-800 ${ }^{\circ}$, Rev. 2, Westinghouse Electric Company, LLC, April 2009.

22. INEEL, Next Generation Nuclear Plant High Level Functions and Requirements, INEEL/EXT-0301163, Idaho National Engineering and Environmental Laboratory, November 2003.

23. INEEL, Design Features and Technology Uncertainties for the Next Generation Nuclear Plant, INEEL/EXT-04-01816, Idaho National Laboratory, June 2004.

24. INCOSE, Systems Engineering Handbook: A Guide for System Life Cycle Processes and Activities, Version 3.2, INCOSE-TP-2003-002-03.2, International Council on Systems Engineering, January 2010. 